\title{
A droga como um recurso ao mal-estar na civilização
}

The recourse to the drug as a malaise in civilization

La droga como un recurso para el malestar en la civilización

Júlia Reis da Silva Mendonça*

\begin{abstract}
Resumo
Este artigo tem como proposta localizar o uso de drogas em relação à função exercida pelo Pai. Dessa forma, o objetivo é apontar a passagem teórica freudiana do uso de drogas que concerne ao Pai, no lugar de Ideal, para o uso abusivo de drogas no contexto do mal-estar da civilização, em que o imperativo superegoico se coloca para os sujeitos. Nossos fins visam a alcançar a compreensão sobre o uso de drogas inscrito na clínica da neurose, e assinalar como Freud elabora a relação sujeito-droga ao longo de seu ensino, em consonância com a teoria das pulsões, conforme localiza o uso de drogas num primeiro momento como recuperação da satisfação pulsional (diante de um excesso de regulação operado pelo supereu) e, num segundo momento, como um recurso que busca amenizar a severidade e a ferocidade do supereu em sua exigência de satisfação.
\end{abstract}

Palavras-chave: uso de drogas; função paterna; supereu; psicanálise.

\begin{abstract}
This article aims to locate the use of drugs in relation to the function performed by the Father. Thus, the objective of this study is to show the passage of the Freudian theory of drug use that concerns the Father, instead of the Ideal, to drug abuse in the context of the malaise of civilization, where the superegoic need arises for the subjects. Our purpose is to understand the use of drugs in the clinic of neurosis, as well as highlight how Freud develops the subject-drug relation throughout his teaching, in line with the theory of drives. Firstly, it describes the use of drugs as the recovery of pulsional satisfaction - when there is an overregulation operated by the superego - and, secondly, as a resource that seeks to lessen the severity and ferocity of the superego's demand for satisfaction.
\end{abstract}

Keywords: drug use; paternal function; superego; psychoanalysis.

Mestra pelo Programa de Pós-graduação em Psicanálise da Universidade do Estado do Rio de Janeiro (UERJ), psicóloga do Hospital Psiquiátrico de Jurujuba, Niterói-RJ. E-mail: juliareis2@yahoo.com.br. 


\section{Resumen}

Este artículo tiene como objetivo situar el uso de drogas en relación con la función ejercida por el Padre. Así, el objetivo es mostrar el paso de la teoría freudiana del consumo de drogas que se refiere al padre, en lugar de Ideal, hasta el abuso de drogas en el contexto del malestar de la civilización, donde el imperativo superyóico se plantea para los sujetos. Nuestros objetivos están diseñados para lograr una comprensión de la droga introducida por la clínica de la neurosis, como señaló Freud para preparar el tema de drogas a lo largo de su educación, de acuerdo con la teoría de las pulsiones, que localiza el uso de drogas, en un primer momento, como recuperación de la satisfacción pulsional, unidad de recuperación - frente a un exceso de regulación aplicado por el superyó - y, en un segundo momento, como recurso que tiene por objeto disminuir la severidad y la ferocidad de la demanda del superyó en su exigencia de satisfacción.

Palabras-clave: el consumo de drogas; función paterna; superyó; psicoanálisis.

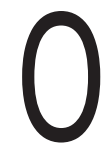

tema do uso e abuso de drogas interessa à psicanálise desde a época de Freud. Apesar de Freud não ter se dedicado especificamente a essa questão, podemos destacar, ao longo da sua obra, alguns momentos em que ele faz referência a tal tema. Eles nos levam a depreender que o uso de narcóticos funciona como um substituto da satisfação sexual faltosa e que a renúncia à satisfação representa a segurança do neurótico diante da moral civilizada. Desse modo, o recurso à substância é concebido, na teoria freudiana, como uma satisfação substitutiva diante do recalcamento e da renúncia pulsional.

Destacamos que as contribuiçóes extraídas da teoria freudiana acerca do uso de drogas concernem a uma época cultural marcada pela moral civilizada e pela consistência do pai simbólico. O pai ideal, que tem a função de suporte identificatório, exige do sujeito a renúncia das satisfações individuais em prol da cultura e garante a perpetuação das injunçôes e proibições por meio do supereu. Não podemos deixar de destacar que as restriçôes morais e sexuais são expressões do poder exercido pelo pai edípico e pelo supereu como herdeiro das catexias advindas do complexo de Édipo.

Contudo a compreensão da função da droga assume suas particularidades quando, diferente da investigação psiquiátrica da época, pautada no modelo 
biológico e nas categorias de hereditariedade e degenerescência, Freud baseia seus estudos na distinção diagnóstica entre neurose e psicose, nos mecanismos de recalcamento e foraclusão respectivamente. Assim, ele demonstra que a psicanálise oferece uma compreensão do sentido e da intenção do sintoma neurótico, e que estes podem ser tratados com base no método psicanalítico.

Conforme o uso de drogas é investigado por Freud, ao considerar os sujeitos de estrutura neurótica, os conceitos de pai ideal e supereu nos ajudam a compreender a articulação entre a função da droga e a função paterna.

\section{A função determinante do pai simbólico}

A tese freudiana sobre o recurso à substância tóxica, ao sintoma e ao tratamento psicanalítico fundamenta-se na clínica da neurose. A partir desta (que teve início com a investigação sobre a histeria), Freud teorizou sobre a morte do pai, elaboração que se encontra de forma detalhada no texto "Totem e tabu" (1912-1913), e, consequentemente, sua permanência como mito na realidade psíquica do ser humano. Dessa maneira, Freud defende que o pai tem função determinante na constituição da neurose, motivo pelo qual podemos estender a interpretação, afirmando que a função paterna é um fator determinante no recurso ao tóxico, compreendido como uma tentativa de amenizar os efeitos do recalque na neurose. Mas como Freud formaliza o conceito de pai ao longo de sua obra?

Freud o apresenta em dois níveis principais: o pai mítico, de "Totem e tabu" (1912-13); e o edipiano, que carrega as simbolizações oriundas da relação dos filhos com as figuras parentais (1924). No primeiro, Freud parte do assassinato do pai para demonstrar que somente com o pacto entre os irmãos após a morte do pai é que a lei pôde ser fundada. No entanto, pelo fato de Freud tratar o tema pela via do mito, a morte do pai será sempre simbólica, pois ele permanece como um ideal e continua a exercer sua autoridade por meio do supereu.

Ele assinala que a organização social, assim como os costumes e as práticas originaram-se na época totêmica. Para esclarecer o que é o pai totêmico, Freud (1912-1913, p. 114) define o totem como um nome que, ao operar como "uma influência decisiva sobre a divisão e a organização tribais, as quais se acham sujeitas a certas normas costumeiras", passa a constituir tanto uma religião como um sistema social "o aspecto social do totemismo se expressa principalmente por uma injunção feita respeitar severamente e uma ampla restrição" (Freud, 1912-1913, p. 113). 
Do mesmo modo, ele relaciona o totemismo à exogamia e ao horror ao incesto, pois os sujeitos do mesmo clã totêmico são proibidos de casar ou ter relaçôes sexuais entre si. Segundo ele, a exogamia antecede o totemismo, já que a lei da exogamia foi instituída para proibir a inclinação dos homens em realizar seus desejos incestuosos:

Desse modo, em vez de presumir da proibição legal do incesto que existe uma aversão natural a ele, deveríamos antes pressupor haver um instinto natural em seu favor e que se a lei o reprime, assim o faz porque os homens civilizados chegaram à conclusão de que a satisfação desses instintos naturais é prejudicial aos interesses gerais da sociedade (Freud, 19121913, p. 129).

No banquete totêmico, ritual presente nas sociedades primitivas, os homens se reúnem para matar e comer o animal sagrado. Apesar da proibição desse ato, ele se justifica pela participação de todos. Todavia, após a morte do animal, os homens se lamentam e entram em um processo de luto. Contemporâneo ao pranto há o festejo da morte do animal, nas palavras de Freud (1912-1913, p. 144): "O sentimento festivo é produzido pela liberdade de fazer o que via de regra é proibido". Freud observa que esse sentimento ambivalente, tanto de respeito como de rivalidade, temor e hostilidade, está presente na sociedade moderna. Assim, há uma equivalência do totem (que impõe as restrições necessárias para a vida harmoniosa em grupo) ao pai, isto é, o animal totêmico é um substituto do pai.

Freud propõe uma abordagem histórica para explicar a origem da escolha de um animal como sagrado, ou seja, o totemismo, e do horror ao incesto, que é baseada na hipótese de Charles Darwin acerca da relação social entre os homens primitivos. Segundo Darwin, esses homens viviam em grupos ou hordas, em que o macho mais velho e forte dominava os outros, impedia a promiscuidade sexual, tinha tantas mulheres quanto podia sustentar e expulsava aqueles mais novos, forçando-os à exogamia. Dessa forma, segundo Freud (1912-1913, p. 131), esse estado social dos homens primitivos produziria, ao longo do tempo, "O que se tornaria uma lei inconsciente: 'nenhuma relação sexual entre os que partilham de um lar comum'. Após o estabelecimento do totemismo, a regra assumiria outra forma: 'Nenhuma relação sexual dentro do totem'”.

Com base nisso, Freud descreve o tipo mais primitivo de uma organização social: a horda primeva. O mito do pai totêmico expressa a violência do pai da horda primeva e seus ciúmes. Ele possui todas as mulheres e as 
proíbe aos demais membros da tribo. Para tal, expulsa os filhos quando chegam à idade adulta, para que não sejam uma ameaça ao seu domínio.

Freud entende que, em algum momento, os filhos expulsos da tribo se reúnem e retornam à horda para matar e devorar o pai. Para terem acesso ao gozo, os filhos assassinam o líder que funcionava de forma autocrática, um pai terrificante que desencadeava angústia. Ao matá-lo, os irmãos colocam fim à horda patriarcal, mas, ao devorá-lo, identificam-se com o pai primitivo com o intuito de adquirir sua força. E, no banquete totêmico, repetem e comemoram em grupo esse "ato memorável e criminoso, que foi o começo de tantas coisas: da organização social, das restrições morais, da religião" (Freud, 1912-1913, p. 145). Desse modo, o sentimento de culpa que poderia advir desse ato é aliviado porque todos do clá participam da refeição.

A comunidade de irmãos, porém, não teve sucesso na organização da sociedade, pois são tomados por um grande sentimento de culpa diante da irrupção, sob a forma de remorso, do sentimento de afeição recalcado, da ambivalência amor-ódio em relação ao pai. Ao colocarem o ódio em prática por meio do assassinato, o amor que estava recalcado surgiu sob a forma de remorso. Esse sentimento de culpa fez com que o pai se tornasse mais forte do que quando era vivo. Como tentativa de solução ao sentimento de culpa, os filhos instituem novas leis, entre elas a proibição do ato criminoso por meio da proibição da morte do totem confirmado como substituto do pai: "Criaram, assim, do sentimento de culpa filial, os dois tabus fundamentais do totemismo, que, por essa própria razão, corresponderam inevitavelmente aos dois desejos reprimidos do complexo de Édipo: o homicídio e o incesto" (Freud, 1912-1913, p. 147).

A cultura e a organização social não foram alcançadas com a morte do pai, somente com o pacto feito entre os irmãos, baseado na renúncia e na partilha. Desse modo, foi necessário que eles deificassem o pai morto para resgatar os tabus e restrições morais necessárias à vida civilizada, assim como Freud afirma nesse texto e repete tempos depois em "Psicologia de grupo e análise do ego" (1921), "O ego e o id" (1923) e "Moisés e o monoteísmo" (1939).

O retorno do pai como autoridade, como um ordenador do gozo, marca a instituição de novas leis e consolida a passagem de uma organização primitiva para a civilização com a inscrição do sujeito na linguagem. $\mathrm{O}$ poder do pai, que era exercido conforme seu desejo é substituído pelo poder da comunidade. Nesse sentido, o pai devastador primitivo se transforma 
no pai simbólico que dita os códigos da lei moral e que funciona como aquele que reforça as exigências do supereu, por meio do cumprimento dos mandamentos e das regras sociais. Assim, mesmo após o assassinato do pai, o gozo permaneceu interditado como efeito do sentimento de culpa gerado nos filhos.

A analogia entre os homens primitivos e os neuróticos é demonstrada pela continuidade dessa situação na Modernidade, enquanto a passagem da horda patriarcal para uma organização social fraterna converge para o complexo de Édipo. Nisso reside o núcleo da neurose, marcado pela a mbivalência emocional em relação ao pai e pelos desejos reprimidos, similares aos tabus fundamentais no totemismo (Freud, 1912-1913, p. 158).

Sendo assim, o assassinato do pai da horda primeva funda a civilização, com o estabelecimento das regras sociais que incidem sobre o gozo, regulando-o. Em certo sentido, o pai da horda é o ancestral do pai edípico. O complexo de castração só pode ser apreendido como consequência de uma época em que o gozo reinava. Somente quando o pai se erige como instância simbólica na necessidade de coibir o gozo é que o pai castrador, proibidor, torna-se um ideal.

Em relação às formulações sobre o pai edípico, Freud assinala que estas têm como ponto central o complexo de Édipo. Apesar de a passagem pelo Édipo ser uma experiência individual (caracterizada pelo amor da criança em relação ao adulto do sexo oposto e ódio em relação ao adulto do mesmo sexo), esse complexo remonta a uma época primitiva, a qual ele resgata sob a forma dos mitos totêmico e edipiano.

Em "Psicologia de grupo e análise do ego", Freud assinala que a identificação é um laço social que está na base do complexo de Édipo: "Um menino mostrará interesse especial pelo pai; gostaria de crescer como ele, ser como ele e tomar seu lugar em tudo. Podemos simplesmente dizer que toma o pai como seu ideal" (Freud, 1921, p. 115). Desse modo, o complexo de Édipo consiste em um investimento libidinal em relação à mãe, que encontra, em algum momento, um obstáculo operado pelo pai na união da criança com a mãe, o que faz com que o menino desenvolva uma hostilidade em relação ao pai.

Nesse texto, Freud destaca que as formações grupais modernas, caracterizadas pela identificação dos sujeitos ao pai, tiveram origem na sociedade primitiva, tal como ele descreveu em "Totem e tabu”, já que o líder do grupo continua sendo temido, tem sede de obediência e dirige o ego no lugar do ideal do ego: 
A nova família era apenas a sombra da antiga; havia um grande número de pais e cada um deles era limitado pelos direitos dos outros. Foi então que talvez algum indivíduo, na urgência de seu anseio, tenha sido levado a libertar-se do grupo e a assumir o papel do pai (Freud, 1912-1913, p. 146).

Freud aprofunda a análise do complexo de Édipo em textos posteriores, como em "O ego e o id", onde marca que, no caso de crianças do sexo masculino, o primeiro objeto de amor é a mãe, aquela que nutre; e o pai é visto como rival que impede a união com ela: "Uma atitude ambivalente para com o pai e uma relação objetal de tipo unicamente afetuoso com a mãe constituem o conteúdo do complexo de Édipo positivo simples num menino" (Freud, 1923, p. 45).

O reconhecimento do complexo de castração (em que o pai impede a relação incestuosa mãe-filho) possibilita a destruição do complexo de Édipo e a entrada do menino na fase fálica. No texto "A organização genital infantil: uma interpolação na teoria da sexualidade", Freud (1923) introduz um acréscimo à teoria ao emparelhar o desfecho da sexualidade na infância com a vida sexual dos adultos, pois a criança deixa de buscar satisfação sexual no próprio corpo e dirige seus investimentos libidinais para uma pessoa. Mas essa solução não é completa na infância, já que somente na puberdade alcança a organização sexual: a pulsão se coloca a serviço da reprodução com a escolha de um objeto de amor à imagem do genitor do sexo oposto, mas diferente deste. $\mathrm{O}$ dado importante do texto se refere à pontuação de que a organização da sexualidade infantil ocorre em torno da fase fálica e não do primado dos genitais: "Para ambos os sexos, entra em consideração apenas um órgão genital, ou seja, o masculino. O que está presente, portanto, não é uma primazia dos órgãos genitais, mas uma primazia do falo" (Freud, 1923, p. 158). Para marcar a diferença entre o órgão biológico e o falo, ele define este último como o representante do órgão, mais além do pênis.

Em "A dissolução do complexo de Édipo", Freud (1924, p. 197) desenvolve essa temática com base na ameaça de castração. A dissolução do Édipo ocorre na infância, diante de uma intervenção do pai no paraíso de cuidados e de amor entre mãe e criança. Ao instituir o complexo de castração, o pai possibilita que a criança se posicione diante do falo e se identifique ao adulto do mesmo sexo. Tal dissolução produz um efeito: a criança internaliza a lei paterna, por meio da formação do supereu, e recalca o eu ideal para construir um ideal do eu, no qual o pai se erige como suporte das identificações. Outro efeito é a interrupção do desenvolvimento sexual, uma vez que a criança subentende o complexo de castração e cai vítima dele. Isso provoca a entrada na fase de 
latência, a suspensão no desenvolvimento sexual da criança, bem como na organização sexual, sendo reativada na adolescência.

Desse modo, o pai, ao interditar a relação dual mãe-criança, submete a criança à lei da proibição de incesto e da lei moral como um todo, tornando possível a formação do sentimento inconsciente de culpa e da consciência moral sob a instância do ideal do eu e do supereu, que é seu tutor. Isso comporta um duplo aspecto: uma obrigatoriedade de ser como o pai e uma proibição de não poder ser como ele, isto é, há coisas que somente o pai tem direito de fazer:

A autoridade do pai ou dos pais é introjetada no ego e aí forma o núcleo do superego, que assume a severidade do pai e perpetua a proibição deste contra o incesto, defendendo assim o ego do retorno da catexia libinal. As tendências libidinais pertencentes ao complexo de Édipo são em parte dessexualizadas e sublimadas (coisa que provavelmente acontece com toda transformação em uma identificação) e, em parte, são inibidas em seu objetivo e transformadas em impulso de afeição (Freud, 1924, p. 196).

Em "Moisés e o monoteísmo", Freud (1939) dá prosseguimento à investigação da função do pai em psicanálise. Ele retoma a situação mítica da horda primeva e verifica que, após a organização de uma comunidade de irmãos, que possibilitou a exogamia e o totemismo, tem início o retorno do recalcado. Se inicialmente havia a adoração de vários deuses, ao longo do tempo, o politeísmo cedeu lugar ao monoteísmo, em que todo poder foi concedido a um deus único, que a imagem do pai primevo passou a ser tanto adorado como temido: "Somente assim foi que a supremacia do pai da horda primeva foi restabelecida e as emoçōes referentes a ele puderam ser repetidas" (Freud, 1939, p. 147).

Esses modelos garantiram a vida em comunidade por meio da renúncia à pulsão, de modo que a renúncia pulsional sob a pressão da autoridade substitui e prolonga o pai. Entretanto, as forças inibidoras à satisfação individual, que eram operadas por fatores externos, sofreram um processo de internalização que originou uma diferenciação no ego e a construção de uma instância que confrontava o restante do ego num sentido crítico. Desse modo, o supereu é a instância que perpetua as proibiçôes e censuras exercidas antes pelo pai; e, ao cumprir esses mandamentos, a criança espera a recompensa pelo amor.

Considerando o processo que leva à renúncia pulsional e ao recalque, compreendemos que, por este, a identificação com o pai na primeira infância se prolonga com a internalização das ordens e proibições, por meio do 
supereu. Por outro lado, os desejos incestuosos ou incompatíveis com o eu são suprimidos. Contudo esses conteúdos que foram recalcados, e que, portanto, tornaram-se inconscientes, podem voltar a se manifestar, por exemplo, por meio dos sintomas.

Freud empreende uma análise do supereu desde o início de suas investigações sobre o aparelho psíquico, pois procura compreender a clínica da neurose e o processo do recalque que estava na base da formação sintomática. Em "A interpretação dos sonhos", Freud (1900-1901, p. 537) apresenta o esquema do primeiro aparelho psíquico composto pelos sistemas consciente, préconsciente e inconsciente. $\mathrm{O}$ inconsciente não é descrito como uma mera oposição à vigília ou ao consciente, mas como um sistema primitivo e amplo que engloba o consciente. $\mathrm{O}$ inconsciente se separa do consciente por uma tela (o sistema pré-consciente) e alcança a consciência somente após deformação da censura. A censura é definida como uma "instância crítica" que, apesar de se localizar entre os sistemas inconsciente e consciente, permanece mais ao lado deste último, na extremidade motora do aparelho, onde também se encontra o pré-consciente. Trata-se de uma instância crítica porque exerce a função de censor do eu ou da consciência.

A definição do supereu (como instância crítica que faz emergir o sentimento de culpa) permaneceu, durante algum tempo, pouco desenvolvida na obra freudiana. Somente no artigo "Sobre o narcisismo: uma introdução", Freud (1914) nomeia essa instância crítica como responsável pela observação e autocensura do ideal do eu. Nesse texto, Freud apresenta uma distinção entre o ideal do eu e eu ideal. O último corresponde a um estado de onipotência do narcisismo na infância, em que a criança é colocada no lugar de ideal para os pais, que lhe atribuem todas as perfeiçôes e a esperança de que realize todos os sonhos que eles não alcançaram: "Ela será mais uma vez realmente o centro e o âmago da criação - 'Sua Majestade o Bebê'” (Freud, 1914, p. 98). O termo ideal do eu é utilizado por Freud para definir uma instância de identificação que fixa as proibições paternas e regula a satisfação da pulsão sexual, que é herdeira do narcisismo; momento em que a criança investe a libido no próprio eu. Contêm múltiplas funções, como a auto-observação, a consciência moral, a censura onírica e tem influência fundamental na constituição dos distúrbios narcísicos, melancólicos e neurose obsessiva, por ocasião do recalcamento.

O conceito de supereu tem origem na confluência do ideal do eu e de uma instância, que teria a função de censura sobre a consciência, apresentada desde os primeiros textos psicanalíticos, como em "A interpretação dos sonhos" (1900-1901, p. 537), em que é apresentada sob o termo "instância crítica". É, portanto, em "O ego e o id” (1923), que Freud marca uma nova definição 
do aparelho psíquico, pois apresenta a instância crítica sob um nome duplo (supereu e ideal do eu), que se encontra mais próxima do inconsciente do que da consciência.

A concepção do supereu e do aparelho psíquico começa a mudar a partir das investigações freudianas acerca do conceito de narcisismo, que traz à tona uma novidade na teoria das pulsões: a possibilidade de investimento da libido não somente nos objetos, mas também no próprio eu. Não resta dúvida de que tal conceito precipitou a sequência de estudos metapsicológicos do período de 1915 a 1919. Por isso os termos libido do ego e libido objetal pertencem à fase de transição da primeira para a segunda teoria das pulsões, de 1920, na qual a oposição entre a pulsão sexual e a pulsão do eu, ou de autoconservação, é substituída pela oposição entre pulsão de vida e pulsão de morte. Freud (1914, p. 83) define duas formas de investimento da libido, uma voltada para o próprio eu (libido do ego, narcísica) e outra dirigida a um objeto exterior (libido objetal): "Há uma catexia libidinal original do ego, parte da qual é posteriormente transmitida a objetos [...], quanto mais uma é empregada, mais a outra se esvazia". Ao observar que, na esquizofrenia, nas neuroses narcísicas e na hipocondria, o investimento libidinal era retirado dos objetos externos para o próprio eu, e, assim, o eu também podia ser investido pela energia sexual, o primeiro dualismo pulsional, entre pulsão sexual e pulsão do eu, passa a ser insuficiente para explicar esses fenômenos clínicos.

Assim, para solucionar esse impasse, Freud (1920) formulou, no texto "Além do princípio do prazer", a segunda teoria pulsional, em que surge uma nova concepção do supereu cuja exigência é de redução do desprazer ou a satisfação a todo e qualquer preço. Nesse texto, ele investiga, com base na teoria e na prática clínica, os sonhos traumáticos, a transferência e o jogo infantil nomeado como fort-da, em que uma criança, ao brincar repetidamente de lançar um carretel para longe, gritando fort (ali), e depois o puxando de volta, exclamando da (aqui, perto), representa a presença e a ausência de sua mãe. Segundo ele, a observação dessas três experiências demonstra a existência de fenômenos que não se restringem aos momentos prazerosos, e que são marcados pela repetição. Através delas, Freud constata que a oposição entre a pulsão do eu e a pulsão sexual não é mais válida para explicar o funcionamento do aparelho psíquico, e, desse modo, submete o aparelho psíquico a um novo dualismo pulsional ao unificar a pulsão sexual e a de autoconservação em pulsão de vida, e contrapô-las à pulsão de morte, a tendência inerente a todo ser vivo de retornar ao estado inorgânico, isto é, livre de tensões. 
Se, na primeira tópica, Freud defendia que o princípio da realidade limitava o prazer (alucinatório, inconsciente), na segunda, ele aponta a presença de algo que está mais além do princípio do prazer. Ao defender que a pulsão é um impulso inerente à vida orgânica cujo objetivo é restaurar um estado anterior de coisas, Freud (1920, p. 49) conclui que "o objetivo de toda a vida é a morte".

Nesse texto, ele assinala uma renúncia pulsional que não ocorre por causa de um ideal e sim da pulsão de morte. Desse modo, os ideais adotados em prol de uma identificação sintomática ao pai ao preço da renúncia da satisfação se tornam uma exigência. A satisfação extraída da renúncia pode ser localizada em Freud por meio do ganho secundário que o sujeito obtém com o sintoma.

A versão final do supereu, que concerne à segunda teoria das pulsões, encontra-se em "O ego e o id", em que Freud (1923, p. 38) retoma os três termos (consciente, pré-consciente, e inconsciente) para redefini-los desde as três instâncias psíquicas: o eu, o supereu e o isso, com destaque para a existência de um eu inconsciente que inclui o material recalcado. Nesse esquema, o supereu é composto por elementos conscientes e inconscientes, e atua como uma instância crítica, julgadora, que submete as açôes do eu às restrições morais e ao sentimento de culpa. Essa terceira instância forma-se por meio de uma gradação no eu que se diferencia a partir da identificação do sujeito com o pai.

O supereu é definido como "o herdeiro do complexo de Édipo", pois, ao recalcar o complexo de Édipo e se identificar com o pai como aquele que possui o que a mãe deseja, o sujeito internaliza a autoridade do pai e submete o eu ao imperativo categórico do supereu.

Apesar da dissolução do Édipo, a pulsão sexual não fica "adormecida" para sempre. Ao ser reativada na adolescência, abre-se para o sujeito uma possibilidade real de concretizar os prazeres sexuais e escolher os objetos sexuais externos. Com a revivência do complexo de Édipo, há um declínio das identificações que eram buscadas à imagem do pai; e o ideal que é posto à prova deve assumir uma nova configuração imaginária em função das novas identificações que se dão a partir do encontro de novos objetos, ideias ou projetos que ocupem para os jovens o lugar de ideal.

Essa investigação sobre o conceito de supereu, e a identificação simbólica ao pai possibilita uma maior compreensão sobre o uso da droga na neurose e a direção do tratamento clínico. 


\section{As primeiras referências freudianas sobre a droga}

Ainda que as primeiras referências freudianas sobre o álcool e outras drogas em suas publicações datem de 1897, Freud inicia suas pesquisas sobre a cocaína em 1885, no artigo intitulado Über Coca. Ali ele apresenta um estudo acerca da história da utilização da cocaína na América do Sul, sua difusão na Europa ocidental, seus efeitos sobre homens e animais, e suas utilizaçōes terapêuticas. Um aspecto importante neste artigo é a presença do referencial fisiológico, evidenciado pela experiência a que se submetiam pacientes e médicos, como Freud, que utilizava a cocaína a fim de observar os efeitos da droga sobre o corpo.

Alguns minutos após ingerir a cocaína, experimentam-se súbita exaltação e uma sensação de leveza. Os lábios e o palato ficam saburrosos, seguindo-se sensação de calor nas mesmas áreas. Em outras ocasiōes, a sensação predominante é um frescor bastante agradável na boca e na garganta. Durante esse primeiro teste, experimentei um curto período de efeitos tóxicos, que não reapareceram em experiências subsequentes. A respiração ficou mais lenta e profunda, e sentia-me cansado e sonolento; bocejava com frequência, sentindo-me um tanto apático. Após alguns minutos, começou a euforia real da cocaína, iniciada por repetida eructação refrescante. Imediatamente após tomar cocaína, notei um leve retardamento do pulso e, mais tarde, um aumento moderado (Freud, 1885 apud Byck, 1989, p. 73).

Ao longo de Über Coca, Freud comenta as utilizações terapêuticas da droga, que apresenta diversas funções para os sujeitos. Ela pode funcionar como estimulante, ao aumentar a capacidade física do corpo por um determinado e curto tempo, ou no tratamento de distúrbios digestivos, da caquexia (degeneração de tecidos), do vício da morfina e do álcool, e da asma. Ele comenta ainda o uso da cocaína como afrodisíaco, "Entre as pessoas a quem administrei a coca, três relataram violenta excitação sexual, prontamente atribuída a ela" (Freud, 1885 apud Byck, 1989, p. 78), e com fins de obter efeito analgésico.

Diferentemente da psiquiatria da época, que procurava, por meio do estudo da fisiologia e da genética, encontrar uma causalidade por trás do uso de drogas, que chegou a ser classificado como um "ato maníaco impulsivo", Freud fundamenta sua investigação na "redução do organismo a uma máquina termodinâmica” e na quantificação da ação da cocaína. O que o levou a teorização da conservação da energia, que ele desenvolve de forma detalhada em "O projeto para uma psicologia científica" (Santiago, 2001, p. 68-71). 
Porém, ao fim desse estudo, Freud constata que os sintomas subjetivos dos efeitos da cocaína são diferentes para cada pessoa e que a ação da cocaína é indireta, efetuada por meio de uma melhora na condição do bemestar. Com isso, se com o uso de cocaína obteve sucesso em relação aos efeitos terapêuticos analgésicos e anestésicos, que permitiram a realização de diversas cirurgias, também demonstrou o fracasso dessa prática, que conduzia ao vício, aos efeitos de intoxicação e até mesmo ao apagamento do inconsciente. Observamos, em nossa prática clínica, que as formaçôes do inconsciente (lapsos, atos falhos, sonhos) estão, em sua maioria, ausentes nos sujeitos neuróticos que fazem o uso abusivo de drogas. Esses sujeitos, que nada querem saber da divisão subjetiva, acabam se afastando da realidade, do convívio social, do trabalho, da família, por causa da ilusão de que a droga lhes proporciona a felicidade e a completude.

Em "Sinopses dos escritos científicos do Dr. Sigm. Freud 1877-97" (Freud, 1897 , p. 225), encontramos uma retomada dos primeiros 15 anos de estudos de Freud, que foram voltados para as ciências físicas. Esse texto relembra que os experimentos realizados com a cocaína confirmaram o notável efeito estimulante e a ação suspensiva de fome, sede e sono. Por esses estudos, Freud se empenhou em oferecer indicações para o uso terapêutico da droga, como, por exemplo, o uso da cocaína durante a supressão da morfina. A expectativa era que a "anestesia" promovida pela cocaína encontrasse outras aplicaçôes. No ano seguinte, publicou dois artigos sobre esse mesmo tema: "Contribuições para nossos conhecimentos sobre os efeitos da coca", em que tratava dos efeitos da cocaína no aumento da força muscular, e "Sobre os efeitos gerais da cocaína". Escreveu ainda "O relatório sobre a cocaína de Parke". Seu último artigo dessa série, intitulado "Comentários sobre a dependência da cocaína e o medo da cocaína", data de 1887 e consiste em uma resposta frente às críticas que vinha recebendo sobre a prática do uso terapêutico de cocaína para alívio da abstinência de morfina. Em sua defesa, ele afirma que a dependência da cocaína só se manifestava em viciados em outras drogas, por isso a própria cocaína não podia ser responsável por causar o vício.

Encontramos, nas Obras completas de Freud, entre os artigos publicados, referências sobre o álcool e outras drogas em uma época em que uma volumosa correspondência acontecia entre Freud e Fliess. Mencionamos aqui duas cartas que falam sobre o uso de substâncias como substitutos da pulsão sexual.

$\mathrm{Na}$ carta 55, ao descrever a sintomatologia de um paciente, Freud (1897, p. 288) assinala que os ataques de dipsomania começavam regularmente 
ou com diarreia ou com catarro e rouquidão, o que denota o envolvimento do sistema sexual oral, e que "a dipsomania surgiu através da intensificação - ou melhor, através da substituição do impulso sexual correlato por esse impulso [para a bebida]". Acrescenta que esse caso pode ser comparado à compulsão ao jogo, a qual assume as características de um comportamento adictivo sem drogas.

$\mathrm{Na}$ carta 79, Freud assinala a dificuldade de tratamento de pacientes que fazem uso de substâncias, ao colocar em dúvida se os vícios poderiam ser curados pela análise. No mesmo viés da carta anterior, ele define a compulsão ao uso de drogas como recurso diante da pulsão sexual não satisfeita. Em outras palavras, Freud (1897, p. 323) defende que as adicções surgem na vida adulta como substitutos da masturbação: "Comecei a compreender que a masturbação é o grande hábito, o 'vício primário', e que é somente como sucedâneo e substituto dela que outros vícios - álcool, morfina, tabaco etc. - adquirem existência”.

Em "A sexualidade na etiologia das neuroses", Freud (1898) também destaca a relação entre a droga e a satisfação sexual. Ele escreve sobre as causas sexuais que determinam as neurastenias, destacando a masturbação como uma das causas possíveis. Nesse texto, continua se questionando acerca da direção de tratamento para aqueles que fazem uso de substâncias tóxicas; e defende que muitos tratamentos fracassam porque os médicos ou terapeutas não incluem as masturbações como hábitos sexuais dos sujeitos. Segundo ele, a cura da neurose ocorre pela retomada da vida sexual normal, sem que o sujeito necessite se satisfazer autoeroticamente e retome seu contato com o outro sexo. Freud defende que essa lógica pode ser aplicada ao tratamento das compulsões. No entanto, a eficácia do tratamento não se observa pela abstinência e sim pela via da satisfação libidinal, já que os narcóticos são destinados a representar o papel de substitutos da satisfação sexual:

O mesmo se aplica a todos os tratamentos para romper com um vício. Seu sucesso será apenas aparente enquanto o médico se contentar em privar seus pacientes da substância narcótica, sem se importar com a fonte de que brota sua necessidade imperativa. O "hábito" é uma simples palavra, sem nenhum valor explicativo. Nem todos que têm oportunidade de tomar morfina, cocaína, hidrato de cloral, etc., por algum tempo adquirem dessa forma "um vício". A pesquisa mais minuciosa geralmente mostra que esses narcóticos visam a servir - direta ou indiretamente - de substitutos da falta de satisfação sexual; e sempre que a vida sexual normal não pode mais ser restabelecida, podemos contar, com certeza, com uma recaída do paciente (Freud, 1898, p. 262). 
Neste mesmo texto ele acrescenta que outros fatores, além do sexual, estariam presentes na causação da neurose. Essa observação torna-se importante para o estudo da etiologia e do tratamento da neurose. Ao criticar o abuso do poder médico, que invade o espaço íntimo do paciente quando interroga sobre assuntos sexuais ou prescreve fármacos que privam o sujeito do estado de consciência, Freud apresenta uma abordagem dos aspectos analíticos e envolvidos no tratamento dos pacientes. As dificuldades presentes no tratamento e também na origem da neurose se relacionam às restrições morais e sexuais impostas aos sujeitos pela cultura.

Em "Os três ensaios sobre a teoria da sexualidade", Freud investiga o autoerotismo presente na sexualidade infantil. Afirma então que, para aquelas crianças cuja significação da zona labial é reforçada, elas serão, na idade adulta, "Ávidas apreciadoras do beijo, tenderão a beijos perversos ou, se forem homens, terão um poderoso motivo para beber e fumar" (Freud, 1905, p. 171-172).

Essas referências textuais localizam o consumo de narcóticos como uma substituição da satisfação sexual que foi reprimida socialmente. Com o recurso à droga, busca-se, então, uma recuperação pulsional. Em consonância com os textos acima, podemos defender que o uso de drogas substitui a masturbação. Quando Freud afirma que a masturbação é a adicção primordial, ele a coloca em íntima relação com o autoerotismo.

A relação direta entre a masturbação e o autoerotismo é trabalhada no texto "Fantasias histéricas e sua relação com a bissexualidade". Na primeira parte, Freud (1908) assinala que a masturbação se divide em duas partes: a evocação da fantasia e a maneira como os sujeitos conduzem a satisfação sexual. Ele destaca que, antes da fusão dessas duas partes que levam à masturbação, há um tempo em que estão presentes os movimentos ativos mecânicos, o puro autoerotismo. Somente num momento posterior é que a fantasia se agrega ao autoerotismo e caracteriza a masturbação.

Desse modo, ele conclui que o sujeito se satisfaz quimicamente tanto pela via interna como pela externa e que há uma relação entre as substâncias peculiares provenientes do metabolismo sexual e a formação neurótica. Assim, ele atribui a causa da neurose às perturbaçôes na vida sexual, e afirma que tal relação mostra "A mais extrema semelhança clínica com os fenômenos de intoxicação e abstinência decorrentes do uso habitual de substâncias tóxicas produtoras de prazer (alcaloides)" (Freud, 1905, p. 205).

Freud continua sua investigação acerca do fator etiológico das doenças nervosas no texto "Moral sexual 'civilizada' e doença nervosa moderna". 
Assinala que as proibições exigidas pela cultura ocasionam sérios prejuízos aos sujeitos, o principal é o aumento da neurose que ele define como a doença nervosa moderna. $\mathrm{O}$ texto trata da distinção entre dois grupos de distúrbios nervosos: as neuroses propriamente ditas e as psiconeuroses. Observa que as psiconeuroses sofrem a influência da hereditariedade e os sintomas desse distúrbio dependem de complexos ideativos inconscientes. Em relação à neurose, ele destaca que os sintomas têm origem no fator sexual e parecem ser de natureza tóxica, e que "comportam-se da mesma forma que os fenômenos que acompanham o excesso ou a escassez de certos tóxicos nervosos" (Freud, 1908, p. 172-173).

A supressão das pulsões exigidas pela sociedade moderna tem como consequência o surgimento dos fenômenos substitutivos: "A vida urbana torna-se cada vez mais sofisticada e intranquila. Os nervos exaustos buscam refúgio em maiores estímulos e em prazeres intensos, caindo em ainda maior exaustão" (Freud, 1908, p. 171). São esses fenômenos que constituem as doenças nervosas, mais precisamente as psiconeuroses. Os neuróticos são sujeitos que, ao terem uma "organização recalcitrante, apenas conseguem sob o influxo de exigências culturais efetuar uma supressão aparente de suas pulsões" (Freud, 1908, p. 177), de tal modo que os sintomas surgem como uma satisfação substitutiva da pulsão sexual recalcada. Posteriormente, ao apresentar a segunda tópica do aparelho psíquico, Freud distingue o recalque, operação primária, da repressão nociva da civilização, que é fonte de mal-estar (Santiago, 2001, p. 100).

Em “O estado neurótico comum”, Freud (1916-1917, p. 388) esclarece o conceito de libido tóxica (que ele havia mencionado no texto "Moral sexual 'civilizada' e doença nervosa moderna"), ao estabelecer a diferença entre neurose de transferência, ou psiconeuroses, e as "neuroses atuais": neurastenia, neurose de angústia e hipocondria. Ambas são satisfações substitutivas, contudo as primeiras são portadoras de um sentido. Assim, Freud acreditava que, ao interpretar os sintomas, eles desapareceriam. Por outro lado, os sintomas das "neuroses atuais" não têm nenhum sentido, nem significado psíquico. Sua manifestação é principalmente no corpo, de tal modo que "mostram uma inconfundível semelhança com os estados patológicos que surgem da influência crônica de substâncias tóxicas externas e de uma suspensão brusca da mesma - as intoxicações e situações de abstinência" (Freud, 1916-1917, p. 388).

Contudo, na segunda teoria das pulsões, Freud localiza a libido tóxica na pulsão de morte. Em presença de um mal-estar na civilização, no qual o supereu se apresenta como imperativo de gozo, a substância tóxica é um 
recurso para amenizar o retorno da pulsão, que é tóxica. Se no primeiro dualismo pulsional o supereu operava como normatizador, relacionado à castração, no segundo dualismo pulsional Freud defende que este está a serviço da pulsão de morte, à destruição através da exigência da satisfação pulsional, que Lacan nomeia como gozo: "Se entende a definição de Lacan quando dá ao supereu o caráter de um imperativo de gozo e o define como uma figura obscena e feroz, este empurrão a um gozo impossível constitui um dos eixos a respeito do supereu" (Sillitti, 2000, p. 128).

\section{A intoxicação como resposta ao mal-estar na civilização}

Há uma diferença marcante entre os textos "Moral sexual 'civilizada' e doença nervosa moderna" (1908) e "O mal-estar na civilização" (1930). Eles apresentam duas concepções diferentes, marcadas pela mudança na teoria das pulsóes, quando localizam o uso de drogas num primeiro momento como recuperação da satisfação pulsional (diante de um excesso de regulação operado pelo supereu), e, num segundo momento, como um recurso que busca amenizar a severidade do supereu em sua exigência de gozo.

A nova teoria da dualidade pulsional entre pulsão de vida e pulsão de morte, a luta de Eros contra Tanatos, fornece subsídios para que Freud escreva "O mal-estar na civilização", que veicula uma nova relação entre humanidade e civilização, em que o imperativo de gozo faz com que os sujeitos recorram à droga como um "amortecedor de preocupaçóes" (Freud, 1930, p. 86), a fim de temperar os efeitos do supereu. Freud assinala ali que a civilização é uma fonte de desconforto do sujeito em sua existência.

Freud afirma ser quase impossível vivermos a vida como ela se apresenta, em função das diversas dificuldades, decepções e exigências que a cultura impõe. Nessa direção, ele aponta sete saídas possíveis ao mal-estar, soluções inventadas pelos sujeitos para se proteger da dor de existir inerente ao mal-estar estrutural da civilização. Inclui o amor, a religião, a atividade científica, a arte, o delírio, a sublimação e os narcóticos como forma de amenizar o mal-estar e buscar a felicidade.

Ele define essas saídas como medidas paliativas para suportar as dificuldades da vida e as agrega em três categorias: os derivativos distrações poderosas que fazem o sofrimento parecer pequeno; as satisfações substitutivas - que reduzem o sofrimento; e as substâncias tóxicas - que tornam os sujeitos insensíveis ao mal-estar. Essas técnicas utilizadas pelo homem para afastar o sofrimento se relacionam com o destino da libido e 
com o investimento pulsional, como podemos observar nos casos em que se procura a satisfação substitutiva por meio da neurose.

Assim, Freud localiza a intoxicação como a solução mais eficaz ao malestar, pois, ao influir sobre o organismo e alterar a química deste, promove efeitos no corpo. A droga ameniza os efeitos do supereu paterno e da exigência civilizatória. Porém o uso de drogas como uma resposta, que objetiva reduzir o mal-estar, tem seus prós e contras. Apesar de causar prazer, apresenta um grande perigo, pois pode levar ao afastamento da realidade e ao isolamento:

Contra o temível mundo externo, só podemos defender-nos por algum tipo de afastamento dele [...]. O serviço prestado pelos veículos intoxicantes na luta pela felicidade e no afastamento da desgraça é tão altamente apreciado como um benefício, que tanto indivíduos quanto povos lhe concederam um lugar permanente na economia de sua libido. Devemos a tais veículos não só a produção imediata de prazer, mas também um grau altamente desejado de independência do mundo externo, pois se sabe que, com o auxílio desse "amortecedor de preocupaçôes", é possível, em qualquer ocasião, afastar-se da pressão da realidade e encontrar refúgio num mundo próprio, com melhores condições de sensibilidade (Freud, 1930, p. 86).

Freud explica a relação do sujeito com as drogas por meio da economia libidinal. Trata-se, portanto, de uma quota de energia que, em vez de se ligar aos objetos do mundo, encontra "refúgio num mundo próprio", impedindo que a pulsão circule na cadeia significante. É comum apreendermos isso na fala do sujeito toxicômano que manifesta o desejo de congelar a sucessão dos fatos, e se apresenta monossilábico nos primeiros atendimentos. Naparstek (2005, p. 24-25) comenta que cada estratégia encontrada pelo sujeito de evitar o mal-estar que, no caso da intoxicação, é promover uma independência frente ao mundo externo por causa dos efeitos químicos no corpo, traz o perigo de se transformar em algo que não se possa mais suportar ou manejar.

Ainda que haja o princípio da realidade mediando a satisfação pulsional e o mundo, o princípio de prazer assume predominância no caso da intoxicação. Contudo, a evitação do sofrimento em prol de um prazer não se dá sem um custo para o sujeito: "Uma satisfação irrestrita de todas as necessidades apresenta-se-nos como o método mais tentador de conduzir nossas vidas; isso, porém, significa colocar o gozo antes da cautela, acarretando logo seu próprio castigo" (Freud, 1930, p. 85). Ou seja, em troca da suposta segurança oferecida pela cultura exige-se algo: a renúncia pulsional. $\mathrm{O}$ uso de narcóticos se situa, justamente, na busca pela restituição de uma parcela da satisfação 
renunciada pela vida em sociedade. Assim, a hipótese sobre o recurso à droga (que, na teoria freudiana, concerne ao segundo dualismo pulsional) é uma formação substitutiva que busca atenuar as exigências do supereu diante da insuficiência do amor ao pai em apaziguar o mal-estar inerente à civilização.

Freud apresenta aí uma nova definição do fenômeno da intoxicação, ao relacioná-lo à civilização e às restrições pulsionais impostas ao sujeito. Ao localizar o uso de drogas entre as medidas paliativas (que são construções auxiliares a serviço do princípio do prazer e que tamponam o mal-estar), Freud define os narcóticos como uma saída diante da desconexão entre a livre realização do desejo e as exigências da cultura, uma muleta que ameniza a dor de existir. Desse modo, a função da droga é considerada como um modo de satisfação da pulsão, uma solução encontrada pelos sujeitos para lidar com o mal-estar próprio da cultura.

Podemos, desse modo, assinalar que a substância tóxica na teoria freudiana é definida como um recurso através do qual o sujeito busca regular a satisfação pulsional tanto pela tentativa da restituição da satisfação sexual renunciada como pela busca de uma pacificação diante do mal-estar na civilização. Porém, se Freud, em "O mal-estar na cultura" (1930), assinala que a solução encontrada para lidar com o mal-estar é singular, e a droga se coloca como uma entre outras respostas, não é isso que observamos na clínica contemporânea. $\mathrm{Na}$ atualidade, os ideais e o casamento feliz com a droga cedem lugar à "toxicomania generalizada", um modo único e globalizado de satisfação (Naparstek, 2005, p. 26). Assim, consideramos, nessa releitura freudiana, que o método químico de intoxicação está ancorado na dimensão ética da felicidade (Santiago, 2001, p. 105), quando o sujeito busca o prazer, a felicidade, ou seja, procura evitar a dor e o sofrimento decorrente da renúncia das pulsões. Dessa forma, a direção de tratamento aponta para a localização do lugar, da função que a droga ocupa para cada sujeito, de modo que ele possa a partir da palavra buscar novas soluções para enfrentar o mal-estar.

\section{Referências}

Byck, R. (1989). Freud e a cocaina. Rio de Janeiro: Espaço e Tempo.

Freud, S. (1996). Extratos dos documentos dirigidos a Fliess - cartas 55 e 79. In: Edição standard brasileira das obras psicológicas completas de Sigmund Freud. (Jayme Salomão, trad., Vol. 1, pp. 288-324). Rio de Janeiro: Imago. (Texto originalmente publicado em 1897). 
Freud, S. (1996). Sinopses dos escritos científicos do Dr. Sigm. Freud 187797. In: Edição standard brasileira das obras psicológicas completas de Sigmund Freud. (Jayme Salomão, trad., Vol. 3, pp. 221-229). Rio de Janeiro: Imago. (Texto originalmente publicado em 1897).

Freud, S. (1996). A sexualidade na etiologia das neuroses. In: Edição standard brasileira das obras psicológicas completas de Sigmund Freud. (Jayme Salomão, trad., Vol. 3, pp. 249-270). Rio de Janeiro: Imago. (Texto originalmente publicado em 1898).

Freud, S. (1996). A interpretação dos sonhos. In: Edição standard brasileira das obras psicológicas completas de Sigmund Freud. (Jayme Salomão, trad., Vol. 5, pp. 521-539). Rio de Janeiro: Imago. (Texto originalmente publicado em 1900-1901).

Freud, S. (1996). Os três ensaios sobre a teoria da sexualidade. In: Edição standard brasileira das obras psicológicas completas de Sigmund Freud. (Jayme Salomão, trad., Vol. 7, pp. 163-217). Rio de Janeiro: Imago. (Texto originalmente publicado em 1905).

Freud, S. (1996). Fantasias histéricas e sua relação com a bissexualidade. In: Edição standard brasileira das obras psicológicas completas de Sigmund Freud. (Jayme Salomão, trad., Vol. 9, pp. 149-154). Rio de Janeiro: Imago. (Texto originalmente publicado em 1908).

Freud, S. (1996). Moral sexual "civilizada" e doença nervosa moderna. In: Edição standard brasileira das obras psicológicas completas de Sigmund Freud. (Jayme Salomão, trad., Vol. 9, pp. 169-186). Rio de Janeiro: Imago. (Texto originalmente publicado em 1908).

Freud, S. (1996). Totem e tabu. In: Edição standard brasileira das obras psicológicas completas de Sigmund Freud. (Jayme Salomão, trad., Vol. 13, pp. 109-162). Rio de Janeiro: Imago. (Texto originalmente publicado em 19121913).

Freud, S. (1996). Sobre o narcisismo: uma introdução. In: Edição standard brasileira das obras psicológicas completas de Sigmund Freud. (Jayme Salomão, trad., Vol. 14, pp. 81-108). Rio de Janeiro: Imago. (Texto originalmente publicado em 1914).

Freud, S. (1996). Conferências introdutórias sobre psicanálise. In: Edição standard brasileira das obras psicológicas completas de Sigmund Freud. (Jayme 
Salomão, trad., Vol. 16, pp. 379-392). Rio de Janeiro: Imago. (Texto originalmente publicado em 1916-1917).

Freud, S. (1996). Além do princípio do prazer. In: Edição standard brasileira das obras psicológicas completas de Sigmund Freud. (Jayme Salomão, trad., Vol. 18, pp. 17-75). Rio de Janeiro: Imago. (Texto originalmente publicado em 1916-1920).

Freud, S. (1996). Psicologia de grupo e análise do ego. In: Edição standard brasileira das obras psicológicas completas de Sigmund Freud. (Jayme Salomão, trad., Vol. 18, pp. 115-126). Rio de Janeiro: Imago. (Texto originalmente publicado em 1921).

Freud, S. (1996). O ego e o id. In: Edição standard brasileira das obras psicológicas completas de Sigmund Freud. (Jayme Salomão, trad., Vol. 19, pp. 27-71). Rio de Janeiro: Imago. (Texto originalmente publicado em 1923).

Freud, S. (1996). A organização genital infantil (uma interpolação na teoria da sexualidade). In: Edição standard brasileira das obras psicológicas completas de Sigmund Freud. (Jayme Salomão, trad., Vol. 19, pp. 157-161). Rio de Janeiro: Imago. (Texto originalmente publicado em 1923).

Freud, S. (1996). A dissolução do complexo de Édipo. In: Edição standard brasileira das obras psicológicas completas de Sigmund Freud. (Jayme Salomão, trad., Vol. 19, pp. 193-199). Rio de Janeiro: Imago. (Texto originalmente publicado em 1924).

Freud, S. (1996). O mal-estar na civilização. In: Edição standard brasileira das obras psicológicas completas de Sigmund Freud. (Jayme Salomão, trad., Vol. 21, pp. 81-148). Rio de Janeiro: Imago. (Texto originalmente publicado em 1930).

Freud, S. (1996). Moisés e o monoteísmo. In: Edição standard brasileira das obras psicológicas completas de Sigmund Freud. (Jayme Salomão, trad., Vol. 23, pp. 117-150). Rio de Janeiro: Imago. (Texto originalmente publicado em 1939).

Naparstek, F. (2005). Introducción a la clínica con toxicomanias y alcoholismo. Buenos Aires: Grama.

Santiago, J. (2001). A droga do toxicômano: uma parceria cinica na era da ciência. Rio de Janeiro: Jorge Zahar.

Sillitti, D. (2000). Toxicomania y clínica del super-yo. In: Sillitti, Sinatra \& Tarrab. Más allá de las drogas. (p. 127-130). La Paz: Plural Editores. 